\title{
Erresilientzia, ahalduntzea eta gizarte-hezkuntza
}

\section{Marta Ruiz-Narezo}

Pedagogia Sozialeko Departamentua, Deustuko Unibertsitatea. marta.ruiznarezo@deusto.es

\section{Janire Fonseca Peso}

Pedagogia Sozialeko Departamentua, Deustuko Unibertsitatea. janire.fonseca@deusto.es

Hirugarren sektorean lanean jarduten dugun profesionalok paradigma-aldaketa bizitzen ari gara. Aldaketa horretan, lagun-egite hezigarriaren garrantzia argi ikusten da, baita talde-lanarena ere, beti ere erabiltzailearen eskuartzea ikuspegi sistemikotik hartuta. Ikuspegi hau osatzeko, erresilientzia eta ahalduntze kontzeptuak azpimarratu nahi ditugu. Bi kontzeptu hauek arrisku-faktoreei aurre egiteko eta erabiltzaileek bizitza "normalizatua" lortzeko erramintatzat ulertzen ditugu. Artikulu honetan gerturatze kontzeptuala aurkezten dugu erresilientzia eta ahalduntze adigaien artean, non elkar eragina duten eskuartzean.

\section{GAKO-HITZAK:}

Erresilientzia, ahalduntzea, gizarte-hezkuntza, hirugarren sektorea.
Los profesionales del tercer sector estamos presenciando un cambio de paradigma en nuestro quehacer profesional. En dicho cambio, observamos la relevancia del acompañamiento educativo además de la necesidad del trabajo en red desde una perspectiva sistémica. Para complementar este enfoque, nos resulta fundamental destacar la resiliencia y el empoderamiento, entendiendo dichos conceptos como herramientas contenedoras de los factores de riesgo y facilitadoras de la consecución de una vida "normalizada" por parte de los usuarios y usuarias. En este artículo realizamos un acercamiento conceptual sobre la resiliencia y el empoderamiento y proponemos un nexo 0 interacción entre los mismos para la intervención socioeducativa.

\section{PALABRAS ClaVe:}

Resiliencia, empoderamiento, educación social, tercer sector. 


\section{Sarrera}

Hirugarren sektorean lanean aritzen garen profesionalok ikuspegi-aldaketa ikusten ari gara azken urteotan. Honetan, aldaketa-prozesuan dauden erabiltzaileentzako askotariko inplikazioak gertatzen ari dira, transformazio pertsonalean eta sozialean baita profesioan bertan ere (De la Paz, Rodríguez eta Mercado, 2014; Juarez eta Lazaro, 2014).

Erresilientzia eta ahalduntze kontzeptuek oso eginkizun garrantzitsua daukate ikuspegi-aldaketa honetan. Bakoitzak, funtsezko baliabideak dakartza interbentzio sozialerako; konkretuki, arriskuan edo bazterkerian dauden ume, nerabe eta beraien familiekin lan egiteko. Artikulu honetan, lehenengoz, erresilientzia eta ahalduntze kontzeptuei buruzko azalpen txiki bat egingo dugu, zeinean ikuspuntu historikoa eta ikerketan gertatutako aurrerapenak eta interbentziorako inplikazioak ikusiko baitira. Bigarren atalean, gertatutako loturak ikusiko ditugu, beraien artean eskuartzerako elementu garrantzitsuenak zeintzuk diren esanez.

\section{Erresilientziaren kontzeptua}

Erresilientziaren kontzeptua duela 50 urte lantzen hasi zen gutxi gorabehera, eta haren jatorria latinetik dator, zehazki "resilio" hitzetik, zeinean erreferentziak esaten baitu "atzera bueltatu, salto batekin edo errebotean”, Becoñaren ustez (2006). Historikoki termino nahiko berria dela kontutan hartuta, esan behar da adituen arteko akordiorik ez dagoela, ez definizioan, ezta bere jatorrian eta azalpenean ere (Martínez-Pampliega et al., 2013).

Normalean, erresilientzia ezaugarri pertsonal edo atributu indibidualtzat hartzen da, baina Arrington eta Wilson-en ustez (2000) arrisku-faktoreak agertzen direnean eta berauei aurre egiten denean ere badugu erresilientzia. Arrisku-faktoreoi aurre egiteko, pertsonaren babes-faktoreak areagotu behar dira, autore hauen ustez. Halaber, erresilientzaren lehenengo azalpenak psikiatria-arloan agertu ziren, traumen ikerketa baten bidez, nazien kontzentrazioesparruetan gertatutakoa analizatu zenean, eta bertan egon ziren pertsonen aurre egiteko gaitasuna eta sendotzea ikusiz (Cyrulnik, 2002, 2008, 2010; Frankl, 1981).

Sortu ostean, kontzeptuaren erabilera handituz joan zen eta beste arlo batzuetan ere erabiltzen hasi zen, hala nola, hezkuntzan eta politika sozialean. Gainera, Cabanyes-en esanean (2010), egoera konkretuetan erabiltzen hasi zen, nahiz eta muturreko gertakarietan ez izan, hain zuzen, bultzatu beharko zen eta beharko litzateke arriskuan zeuden eta dauden pertsonen garapenerako. Rutter-ek (2007) erresilientzia definitu zuen pertsonak, nahiz eta arrisku-egoeretan egon, emaitza positiboak lortzeko gai direla esanez. Aldiz, beste autore batzuen esanetan, Aldwin (2007) eta Smith eta Prior-en
(1995) ustez, erresilientzia ez da ezbeharren aurreko erresistentzia soilik, erresilientzia ezbeharren aurrean hazteko eta garatzeko aukera ezin hobea da.

Egoeraren arabera, pertsona bakoitzaren erreakzioa ezberdina izango da, eta influentzia askorengatik gertatuko da ezberdintze hori: egoera pertsonala, momentu horretako testuinguruko gertakariak, etab. Erresilientzia arrisku- eta babes-faktoreek modulatuko dute arrisku- edo ahultasun-egoeretan; eta bultzatzaile edo zirikatzaile moduan jokatzen dute arrisku-faktore horiek, eta kontrolatzaile moduan babes-faktoreek.

Eredu ekologikoa edo sistemikoa erresilientziarekin oso lotuta eta erlazionatuta dago. Bronfenbrenerrek (1987) dio erresilientzia pertsonen baliabideekin lotuta egongo dela, arrisku-egoerei aurre egiteko gai izango dela; baldin eta, horretarako, erreminta batzuk baditu. Gainera, inguru positibo batek zorigaiztoko egoerak gainditzea bultzatu ahal duela eransten du; eta inguru negatiboa edo arriskuan dagoenak berriz, jarduera arriskutsuak agertzea bultzatu ahal duela. Ungar-ek (2010: 435) esaten zuen:
Zorigaiztoko egoera batean, erresilientzia pertsonaren gaitasuna da, hainbat baliabide eskuratzeko: psikologikoak, sozialak, kulturalak eta fisikoak -haren ongizate eta ahalmen pertsonalari eta komunitarioari eusten diotenak-. Hartara, baliabideen negoziazioa eragile guztion artean burutu beharko da, ikaskuntza esanguratsuak izan daitezen.

Erresilientzia-prozesu moduan ulertzen dela onartuz, zeinean pertsonak eta bere inguruneak eragin handia edukiko dutela esaten baitugu, perspektiba sistemikoa hurrengo mailetan bana dezakegu: alde batetik, maila mikroa agertzen da, bi edo hiru pertsonen arteko erlazioari dagokionez eta maila makroari, non erlazio orokorragoak ikusten diren, komunitatean gertatutakoak, hain zuzen. Ezberdin ditzakegu inguruko faktore eta faktore pertsonalen artean, erresilientziari buruz ari garenean (Pérez Blasco et al., 2007 eta Vinaccia, Quiceno, eta Moreno San Pedro, 2007).

Kasu honetan, Brofenbrenerrek (1987) aurkeztutako nerabeen sistema horietan sakonduko dugu: familia-, eskola-, lagun- eta komunitate-sistema edo komunitarioa; argi edukita baliabide pertsonalak oso inportanteak direla erresilientzia-prozesuan, baina sistema hauek influentzia izugarria edukitzen dutela prozesu osoan. Horregatik, gizarte- hezitzaileentzat lagungarria izan ahal den argudioa dela pentsatzen dugu:

1. Sistema familiarra: Bertan familiaren faktore genetikoak eta hereditarioak agertzen dira, eta influentzia soziokulturala ere bai. Izandako sostengu familiarra, egondako klima eta guraso eta anai-arreben arteko loturaz gain, giroak influentzia izugarria izango du pertsonan, eta 
erresilientzia garatzeko gaitasunean; azken finean, sozializazioa gertatzen den lehenengo lekua baita.

2. Eskola-sistema: Ikaskuntzen sortzailea da, zeinean eguneroko praktiken bidez, ikasketa horiek barneratzen baitira, arazoak nola konpondu eta trebetasun sozialak ikasteko eta nerabeen kapazitate kognitiboak, erlazioak eta hiritartasuna jorratzen dira, konpromisoa hartuz maila lokalean eta globalean.

3. Lagunen sistema: Oso garrantzitsua bihurtzen da nerabezaroan, lagunek eragin nabarmena dutelako eta beraien pentsamenduak eta jarrerak antzera egiteko joera izaten delako. Taldearen partaide izatea eta balio moral berberak jarraitzea, beste faktore batzuen artean, erabakigarri izango dira, nerabeak jarraituko baititu eta horrek besteon jarreren erreprodukzioa bultzatuko baitu.

4. Sistema komunitarioa: Nerabearen inguru sozialak influentzia handia edukiko du, hala nola, hura bizi den auzotegiaren giroa, identitate soziala, kulturala, etnikoa, arauen barneraketa eta bertan dauden agente komunitarioek izugarrizko eragina edukiko dute nerabeetan.

Gainera, esan dugun moduan, nerabezaroa bizitzaren tarte labur bat da, eta bertan agertzen dira aldaketa fisikoak, psikologikoak eta iritzi soziala. Horretarako, eskuartze egokia prestatu beharko da, erresilientzia bultzatzen duena, eta kontuan hartzen duena pertsona eta bere ingurua, hau da, eskuartze egoki bat, zeinean maila guztiak kontuan hartzen direnak, pertsonala/indibiduala, soziala/komunitarioa, lagunena, heziketakoa eta familiakoa. Aldaketak pertsonan berarengan igarriko dira, baina baita bere inguru hurbilean ere (Pereira, 2011).

Erresilientzia ez da ezaugarri estatiko bat, ezta pertsona berak bizitzan zehar mantentzen duen nolakotasuna ere. Erresilientzia ez da eraso ezinaren sinonimoa. Pertsona bat, egoera konkretu baten aurrean eta bere bizitzaren momentu zehatz batean, erresiliente izan ahal da, baina ez gero, beste ezbehar baten aurrean. Ezberdintasun hau ezaugarri pertsonalek, egoera sozialak, kulturalak, ekonomikoak eta ingurunean kokatzen diren pertsonon influentziengatik gerta daiteke. Rutter-en (1987) hitzetan, babes-faktore bat bizitzaren beste momentu batean arrisku-faktore bihurtu ahal da, eta alderantziz. Erresilientzia-prozesu erlazional bat bezala ulertu behar da, eta ez ezaugarri indibidual gisara. Erresilientzia gertatzen den ingurunea oso inportantea izango da, ezinbestekoa, eta horregatik arreta eman beharko diegu bertan parte-hartzen duten pertsona guztiei, erreminta hezitzaileak eskainita, haien babes-faktoreak bultzatzeko eta arazoei aurre egiteko gaitasuna gara dezaten.

Lehenengo ikerketak eskizofreniaz diagnostikatutako pertsonei buruzkoak izan ziren; konkretuki estresa eta pobrezia larria jasaten zutenei buruzkoa (Garmezy, 1974), eta traumak edukitako pertsonak ziren haien bizitzaren lehen etapetan (Cicchetti, 2003). Familiekin, umeekin eta nerabeekin Werner-ek aurrera eraman zuen ikerketa (Werner, 1989; Werner eta Smith, 1982) oso garrantzitsua izan zen, non Hawaiin egindako ikerketen datuak azaltzen diren. Arazo larriak eduki zituzten umeekin egin zen ikerketa, eta bertan espero zena baieztatu: nahiz eta arazo larriak eduki eta gizarte bazterkerian zeuden familietakoak izan, ume askok bizimodu arrakastatsua izatea lortzen zuten. Beraz, ondorioztatu zenez, garapena ez dago lehenengo momentutik baldintza negatiboen mende. Ikerketan parte-hartutako umeetatik \% 8ok eboluzio positiboa lortu zuten; eta, azkenean, gizarteratutako eta trebetasunak zituzten heldu bihurtu ziren (Vinaccia, Quiceno, eta Moreno, 2007).

Estatu espainiarrean egindako ikerketak analizatu nahian, Oliva eta beste egile batzuk (2008) egindako ikerketari egiten diogu erreferentzia. Bertan, 12 eta 19 urte tarteko 513 nerabek parte-hartu zuten Sevillako 10 zentrotan, eta bertan (2008: 60-61) esaten zuten: "Oro har, ikerketa honetako emaitzak bat datozela esan dezakegu arrisku- eta erresistentzia-ikerketekin, eta horietan proposatzen da familia harremanak direla babes-faktore nagusienak neska-mutilak babesteko gertaera estresagarrien eragin okerretatik (Jackson eta Warren, 2000; Quamma eta Greenberg, 1994; Luthar, 2006)". Halaber, haurtzaroan eta erdialdeko eta amaierako nerabezaroan babesten dituzte, nahiz eta amaierakoaren ebidentzia enpiriko gutxiago izan (Maggs et al., 1997; Masten et al., 1999; Muñoz-Rivas eta Graña, 2001). Horrek guztiak, interes handiagoa ematen die emaitza hauei, parekoen eragina gero eta handiagoaren gorabehera, nerabezaroko jokaerak doitzean, familiak jarraitzen duela izaten babes-eragin garrantzitsu erakusten baitute.

\section{Ahalduntzearen kontzeptua}

Beijingen egindako Emakumeen IV. Mundu Konferentzia arte ahalduntzearen kontzeptua ez agertu arren (Nazio Batuak, 1995), aurretik kontzeptuaren oinarri teorikoari ekarpenak egin zizkieten hainbat mugimendu sozialetako (eskubide zibilen alde Estatu Batuetan 60-70ko hamarkadetako mugimenduak, adibidez) eta hezkuntza-arloko egile izan ziren (Freire, 1975 edota Ivan Illich, 1971). Oinarri hauek botere banaketa desberdinean zentratu ziren, baita bazterketa-egoeran zeuden talde desberdinek pairatzen zituzten egoera diskriminatzaileetan ere (Fredericks, 2008).

Aurreko ataleko erresilientzia terminoarekin ikusi den bezala, kasu honetan ere, ez dago adostasunik ahalduntzea definitzeko orduan, eta izandako garapen labur honetan, diziplina anitzetatik eztabaidatua izan da (ekonomikoa, kulturala, soziala eta politikoa). Errealitate honen aurrean, hainbat egilek adostasuna beharrezkoa dela defendatzen dute, eta hori egin ezean, "ohitura osasungarri”, “autonomia” edota "ongizatea” 
izatearen sinonimotzat hartzeko arriskua dakarrelako (Tengland, 2008), eta giza aktibismoa eta giza transformazioa lortzeko duen benetako ahalmen teoriko-praktikoa ahazteko arriskua izan dezakelako (Leonardsen, 2007; Lord eta Hutchison, 1993; Parra Ramajo, 2014).

Beraz, izaera holistiko eta multidimentsionala daukan kontzeptu baten aurrean gaude, eta nahitaez, eztabaidagarri bilakatzen da. Adibidez, Rubio Serranok (2014) ahalduntzea prozesu iraunkorra dela deritzo; Zimmerman-ek (2000) edo Rodríguez Fernández, Salvador Pedraza eta Hernández Echegaray-k, ostera (2014), bai prozesutzat, bai helburutzat ulertzen dute. Zimmerman-en aburuz (2000), ahalduntzea da norberak edota elkarteak eta komunitateak esperimentatzen duten boterearenganako kontrola izateko prozesua eta helburua. Egilearen ideiarekin jarraituz, esan dezakegu, beraz, ahaldunduta dauden pertsona, elkarte eta komunitateak daudela. Escudero Espinalt egileari jarraituz (2014: 34), desirak gauzatzeko gaitasuna ahalbidetzen duen boterea ahalduntzea da, aldaketak eragin eta beharrizanak asetzen dituena. Egilearen iritziz, pertsonok barneratzen ditugun indarretan, hierarkietan, errekurtsoen kontrolpean eta roletan islatzen da.

Nahiz eta adostasunik ez egon, definizio guztietan beti agertzen dira hiru kontzeptu: boterea, kontzientzia eta prozesua. Llobet Estany-ren esanean (2014: 460):

Denboran zehar aktibatzen den mugimendu bati egiten dio erreferentzia, eta bi dimentsioren arabera ardazten da. Bata, "boterearen” arabera, eta bestea, ikaskuntza-prozesu baten ideiaren arabera, boterera iritsi ahal izateko.

Boterearen kontzeptuan sakontzeko, Rowlands-ek (1997), lau botere mota desberdintzen ditu. Emakumeen kolektiboan oinarritu zen bere sailkapena egiteko, baina edozein kolektibora estrapola daiteke: "boterea norbaiten gainean”, "boterea barrutik", "boterea norbaitekin" eta "boterea edozerretarako". "Boterea norbaiten gainean”, o emaitzako boterea adierazten du, non pertsona baten boterearen areagotzeak bestearen boterearen murrizketa dakarren. Aldiz, beste botere mota guztiak positiboak dira (Picaza et al., 2015). Horregatik, Rodríguez Fernández, Salvador Pedraza eta Hernández Echegaray egileek (2014: 233) proposaturiko eskuartzeak ez du ahalduntzeprozesuetarako "boterea norbaiten gainean" aintzakotzat hartzen. Egile hauen esanetan, beste hiru botere moten barruan, begietsi behar diren gaitasun desberdinak daude:

- Boterea zertarako: erabakiak hartu, norbanako identitatea izan eta gaitasunak bereganatzen joateko, bai arazoak konpontzeko, bai pertsonak berak nahi dituen ekintzak modu autonomo batean egin ahal izateko. "Jakin" eta "egiten jakin” gaitasun intelektualei egiten die erreferentzia, baita onurak lortzeko beharrezkoak diren errekurtsoen sarbidea nola lortu jakiteari ere.

- Boterea norekin: botere soziala eta politikoa, solidaritatea eta autolaguntza ideiatik, guztion helburu dena defendatu ahal izateko antolatzen den gaitasuna (norbanako eta taldeko eskubideak, ideia politikoak, sozialak...); sare sozialean parte-hartzea eta erlazionatzen jakitea. Ikuspuntu kolektibo batetik, botere honek sozialki antolatzeko eta parte-hartzeko gaitasuna dakar, guztiona den helburu bat lortzeko edo ikuspuntu berbera elkar banatzeko.

- Barruko boterea: norbanako irudikapena, autoestimua, identitatea eta indar psikologikoa (izaten jakin). Banakakoari edo subjektibotasunari egiten dio erreferentzia: pertsonak autoanalisia eta norbanako gaitasunen aurkikuntzan, bere bizitzarekiko influentzia izateko gaitasuna eta aldaketak nola proposatzen dituen.

Ahalduntzearen definizioan ikusitako bigarren kontzeptuan zentratuz (kontzientziazioa), Freireren (1975) ikuspuntu “arazo-sortzailea” oinarritzat daukala esan dezakegu: gaitasunaz eta ahalmenaz jabetzeko aukera ematen du, eta, aldi berean, pertsonok gizartearekiko sortzen dugun erlazioa ulertzea ahalbidetzen du (Torres del Castillo, 2009). Ildo honetatik, Mollenhauer-en teoria kritikoan oinarritzen bagara, "kontzientziazioa” ekintza sortzeko aurretiko pausoa da. Baina Banks-ek (2004) gogorarazten digun bezala, ekintza bera gidatzen dituen erremintak beharrezkoak dira, justizia soziala aldarrikatzen eta bermatzen dituzten erremintak. Egilearen ustez, esperantza barik kritika egiteak etsipena eta "agentzia” faltaren sentimendua eragin dezake. Horregatik, kontzientziazioarekin batera, erremintak eskainiz gero, pertsona bakoitzak ekintza eraldatzaileak martxan jar ditzake, eta bere konfiantza-maila, autoestimua eta beharrizanei erantzuna emateko gaitasuna areagotu (Escudero Espinalt, 2014).

Aipatutako agentzia terminoa ahalduntzearekin erlazio estua duen kontzeptua da, autonomia, autodeterminazioa, liberazioa, partaidetza, mobilizazioa eta norbanako konfiantza terminoekin batera (Narayan, 2005; Rodríguez-Casadevall, Morata eta Muro, 2014). Agentzia terminoak pertsona edota elkarte batek modu libre batean aritzeko gaitasunari egiten dio erreferentzia (Bandura, 2001; Sen, 1985). Sen (1985) eta Kabeer egileen ustez (1999), agentzia ez da bakarrik ekintzarako gaitasuna; aurretik, ekintza honekiko asmoa behar da, esanahia, motibazioa eta helburua.

Hirugarren kontzeptua, hots, prozesua, erreminta boteretsu bilakatzen da. Pertsonen eta taldeen ezagutzak, trebeziak, balioak eta motibazioak batzen ditu, hauek esfera publikora salto egin dezaten, euren komunitate eta gizarte orokorraren garapenari laguntza eman ahal izateko (Shaw et al., 2012). Horrela, Crespo eta beste batzuek (2007) 
ahalduntzearen hiru dimentsio erlazionatzen dituzte: soziala (elkarte indartsuak, zilegizkoak eta ordezkagarriak), politikoa (gobernagarritasun demokratikoa) eta ekonomikoa (autonomiarako aukerak sortzekoa).

Maiztegui (2011) harago joaten da, eta onura pertsonalen eta sozialen arteko bereizketa egiten du bizitza publikoaren esparru desberdinetan. Egilearen ustetan, eremu osagarriak dira: ikuspuntu pertsonaletik botere pertsonalak finkatzen dira, autoestimu eta garapen pertsonala garatzea bilatuta; ikuspuntu kolektibotik, taldeak gizartean parte-hartzeko gaitasunari egiten dio erreferentzia, baita kideen arteko igarpenari, autoritate eta boterearekin ekiteari eta euren bizi-baldintzen hobekuntza bilatzeari ere. Azkeneko ikuspuntu honetan, Rubio Serranok (2014) bereizketa egiten du: alde batetik, "dimentsio kolektiboa”; eta, bestetik, “dimentsio soziala”. Lehenengoan, Maizteguik (2011) aipatzen duen igarpena egongo litzateke, hots, lokarrien sendotzea eta guztien arazoei aurre egiteko ahalbidetzen dituzten euskarriak bultzatzea, guztien interesen defentsarako bidean. Bigarrenean (dimentsio soziala), bizi-baldintzen hobekuntzei egiten die erreferentzia, taldeko aldaketak honetan sortzen baitira.

Laburbilduz, ahalduntze terminoak pertsonak, taldeak edota komunitateak boterea eskuratzeprozesuari egiten dio erreferentzia, baita modu autonomoan aritzeko gaitasunari ere. Beste modu batean esanda, aldaketa paralelo bat ahalbidetzen duen prozesuari egiten dio erreferentzia, bai pertsonala, bai taldekoa, norberaren bizitza ri buruzko kontrol- eta erabakitze-botere gehiago izateko bilakaeran (Kabeer, 1999). Parra Ramajoren aburuz (2014), prozesuan zehar partaideen ezagutzak eta esperientziak balioesten dira, partaidetzaren bitartez euren ahotsak egiaztatu eta euren trebetasunak areagotuta (norbanako arazoak definitzeko, aztertzeko eta horiengan ekiteko, baita desberdintasun egoerak eraldatzeko ere).

\section{Erresilientzia eta ahalduntzea: txanpon beraren bi aldeak}

Artikuluan zehar aztertutako bi kontzeptuek izan ditzaketen inplikazioen inguruan eztabaida sortzea eta eskuartzerako funtsezkoak bilakatzen diren elementu eztabaidagarriak aipatzea da atal honetako helburua.

2013. urtean, beste argitalpen batean (Santibáñez et al., 2013), arrisku-egoeran dauden haur, nerabe eta haien familiekin lan egitean ageri diren eskuartze eraginkorren inguruan idatzi genuen. Hartan, pertsonaren protagonismoa azpimarratzen genuen, Haurren Eskubideen Hitzarmenean oinarrituta. Adingabeen eta familien protagonismoa aldarrikatzeak aurreratze bat ekarri $\mathrm{du}$, izan ere, haien gaitasunen onarpena inplikatzen baitu. Erresilientzia terminoa gehitzerakoan, arrisku-faktoreekin batera, babes- faktoreak ere dituztela ohartzen gara, baita egoera latzen aurrean berritzeko, eusteko, hazteko eta garatzeko gaitasunak ere. Aurrera eraman behar diren egoera hauen aurrean, haurrak eta nerabeak izaera indibidual, pertsonal eta psikologikoa duten baliabideak martxan jartzeaz aparte, izaera sozialeko eta pertsonen arteko baliabide eta euskarriak ere gehitzen dituzte.

Horrela, defizitaren ikuspuntua gainditzea lortzen dugu, gabetasunetan, beharrizanetan eta arazoetan oinarrituta baino ez dagoena, eta "sendotasun ikuspunturantz” zuzentzen gara (Juárez eta Lázaro, 2014: 147). Autore horiek, hainbat printzipio aipatzen dituzte, eta horietatik batzuk goraipatu nahiko genituzke, nahiz eta esperientzia txar guztiak mingarriak izan, era berean, badira aldaketak egiteko aukerak eta sendotasunak aktibatzeko momentuak (pertsonok dauzkagun gaitasunak, familia barne egonda). Aldaketa hauek pertsonaren barnehazkunde bat dakarte, pertsonen arteko erlazioak eraikitzeko eta bizitzaren inguruko ikuspuntu filosofikoa eta zentzu espirituala garatzeko.

Erresilientziak aukerak eskaintzen dizkigu profesionaloi. Paradigma aldaketa suertatzen da, indarretan oinarritzen dena, eta eskuartzean, bai pertsonak, bai euren familiak, taldeak, komunitateak eta elkarteak barne hartzen dituena, agente oro konponbidearen parte izan daitezen (Quintero, 2005).

Pertsonen ahalmen erresilientea sustatzeko, ahalduntze-prozesuetan sartu beharko ditugu, beharrezkoa dutenean, jarrera erresilientea aurkezteko kapaz izan daitezen. Juarez eta Lázarok (2014), erresilientziaren oinarrien artean, honako hauek aipatzen dituzte: interakzioak edo erlazioak, atxikimendu estuak eta sendoak, eta atxikimenduaren eta euskarrien sorkuntza, besteekiko maitasuna sentiarazteko.

Gizarte- eta hezkuntza-esparruko ahalduntzeprozesuetan lan egitean, argi eduki behar dugu, programak diseinatzeko, idatzi beharreko helburuak bideratuta egon behar direla parte-hartzaileen erabakien kontrolera eta maila indibidual eta komunitarioan aldaketa positiboak aktibatzeko errekurtsoen hornikuntzara (Rodríguez-Casadevall, Morata eta Muro, 2014). Jomuga, Straub-en ideiari jarraituz (2011), parte-hartzaileen jarrera-aldaketa positiboa sortzeko, gaitasuna areagotzea izango litzateke modurik egokiena, haien ikuspuntuak eta helburu pertsonalak barneratuz. Horregatik, eskuartzea trebezien garapenera bideratuta egon behar da, arazoak konpontzeko eta erabakiak hartzeko orduan burujabe izateko.

Hala ere, terminoaren konplexutasuna dela eta, baita ikuspuntu sinplistetan arriskuan jauzteko aukerak murrizteko asmoarekin ere, ahalegina egin behar da ahalduntzearen neurketa egokia egiteko. Horrela, bai prozesuak, bai Zimmerman-ek (2000) aipatutako 
ondorioak aztertu ahal izango dira: alde batetik, pertsonak edota taldeak egiten dituzten saiakerak, botere gehiago lortzeko; beste alde batetik, ahalduntzea lantzeko diseinatutako eskuartzeen ondorioak. Neurketa-esfortzu honetan, Rodríguez Fernández, Salvador Pedraza eta Hernández Echegay autoreek (2014: 224) ahalduntzearen segimendua ahalbidetzen duten adierazleak proposatzen dituzte:

- Maila indibidualeko adierazleak: eskuartzea egiten den pertsonekin haien bizi-proiektua nola eramaten duten aurrera jarraitzeko adierazleak dira. Ahalduntze subjektiboa baloratu behar da, honako premisarekin: "hautazko aukera gehiago" izan eta, bizi kalitatea hobetzeko, aukera horiek aprobetxatu.

- Maila kolektiboko adierazleak: aldaketa sozialaren jarraipena ahalbidetzen dute, seguruagoa eta bidezkoa den testuinguru komunitario bat eraikitzeko: kideak batzeko eta mekanismo desberdinak martxan jartzeko aukera ematen duena, bizi-proiektuak garatzeko, bai emakumeei bai gizonei aukera eta eskubide berberak eskaintzen dizkiona.

Honako adierazle hauek Montagut-ek (2008) proposatzen duen eskuartze ideia gogorarazten dute. Egilearen aburuz, profesionalak bi eginkizun nagusi dauzkagu eskuartzean: lehenengoa, "gaitzailea" izatea, hots, herritartasun-jarduera ahalik eta pertsona gehienek gozatu ahal izatea, "desgaitasun soziala” (111. or.) pairatzen duten kolektiboak azpimarratuz; bigarrena, politika publikoen agenteak izatea, eremu parte-hartzaileak sortzearen eta lehen aipatutako pertsonen barneratzearen zereginekin, euren herritartasun-eskubideak gauzatu ditzaten (117. or.). Ondorioz, programak sortzerakoan, bi dimentsioak batu beharko dira, ahalduntze eraginkorra eta iraunkorra bermatzeko.

Ahalduntze kontzeptuarekin amaitzeko, eskuartzea egiteak dakartzan erronkak aipatzekoak dira. Escudero Espinalt-ek (2014) funtsezko bi aipatzen ditu. Alde batetik, benetako parte-hartze prozesuen garapenaren sustapena; teorian ikusitako onurak lortu nahi badira, eskuartzea benetako prozesu parte-hartzaile batean oinarritu beharko da, erlazio horizontal batetik, boterea banatzen duena. Bigarren erronkak Montagut-en (2008) diskurtsoa gogorarazten du, eta errekurtsoen aktibazioari dagokio. Bilatu beharreko errekurtsoak, Montagut-en aburuz (2008: 41), aldaketak ahalbidetzen dituzten egiturak izan behar dira, integraziorako lorbideak izan behar dira, baztertuta edo bazterketa-arriskuan bizi diren kolektiboek haien abaguneak eragindako zaurgarritasun-egoerak gainditu ditzaten.

Beraz, Escudero Espinalt-en aburuz (2014), eskuartzea egitean, aspektu patologikoak alde batera utzi behar ditugu, gaitasunetan eta boterearen eskurapenean zentratzeko. Trevitchik-en (2006: 217) ideiei jarraituz, ikuspuntu psikologiko batetik, lau alderdi izan behar ditugu kontuan eskuartzea egiteko:
- Norbanakoaren eraginkortasuna garatzea, hots, erreakzioetatik akziora pasatzea. Aldaketa honek, pertsonaren norbanako prozesuan, parte-hartze aktiboa izatea ekarriko du.

- Talde-kontzientzia garatzea. Pertsona bakarrik ez dagoela ohartzea, baizik eta komunitate bateko partaide dela eta inguratzen dion testuinguruak eraginda dagoela.

- Bere buruari errua botatzeko joera murriztea. Askotan, biktimari "biktimizatzen" utzi behar diogu, eta berarekin lan egin, bizitzaren zailtasunak gainditu ahal izateko.

- Aldaketarekiko ardura pertsonala onartzea. Nahi den aldaketa lortzeko, konpromisoa eta lankidetza beharrezkoa da.

- Autore berberak profesionalen ikuspuntutik jarraitu beharreko estrategia eta teknika zehatz batzuk jarraitzea garrantzitsua dela aipatzen du, hala nola (Trevithick, 2006: 218):

- Hartzaileak arazoarekiko duen ikuspuntua onartzea. Honetatik abiatuz, profesionalak hartzailearekin batera arazoari aurre egiteko eskuartzea definitu eta adostu beharko ditu.

- Arazoa osotasunean ulertzea, hartzailearen lekuan jarriz eta enpatia erabiliz, hartzaileari hobeto laguntzeko.

- Gatazken konponketarako berariazko trebeziak irakastea. Horretarako, ikuspuntu erresilientea baitan hartzen duen eskuartzea garatu beharko da, dauden zailtasunak identifikatzea ahalbidetuko duena, eskuartzean sartzeko eta hauek gainditzeko.

- Baliabideak mobilizatzeko eta hartzaileen duintasuna defendatzeko gaitasuna izatea.

Gizarte-hezkuntzako profesionalentzat, planteamendu aldaketa hau akonpainamendurolean oinarrituta dago, eta ez eskuartze gidatu batean. Juarez eta Lazarok (2014) baieztatzen zuten 6o. eta 70.eko hamarkadan sortu zela ahalduntze kontzeptua, mugimendu zibiletan oinarrituta, eta eskuartze-munduan erabiltzen hasi zela jarrera paternalistei eta haur kutsukoei aurre egiteko, momentu horretara arte horrela egiten baitzen. Ahalduntzeak profesionalok erabiltzaileei eta komunitateei boterea bueltatu behar diegula esaten du. Horrek esan nahi du pertsona guztiek, baita erabiltzaileek ere, boterea daukatela, hau da, babesfaktoreak eta indarguneak, eta aldaketa errealak gertatzeko tartea daukatela.

Rodrigo, Maíquez eta Martínek (2010) esaten zuten moduan gogoratu behar dugu gizarte-hezkuntzan interrelazioa eta interkomunikazioa edukitzeko gaitasuna egon behar dela, pertsona, familia, lagun, komunitate eta agente sozialen artean, betiere haien akonpainamendua eta ahalduntzea sustatuta. Era berean, erabiltzaileek tresnak barneratzea lortu behar dute, eta kasu bakoitzean desberdinak izango dira. Horretarako, ikuspegi koordinatua eta arriskueta babes-faktoreen arteko oreka lortzeko gaitasuna erakutsi beharko dugu gizarte-hezitzaileok. 
Parte-hartzeak eta erresilientziaren bultzadak garapen pertsonala eta konfiantza handitzea lortuko du, hala nola, aukerak hartzeko gaitasuna, eta, hortaz, balio demokratikoak eta eskubideen zaintza bultzatuko dira, herritar onak eta garapen psikosozial egokikoak. Horretarako, gizarte osoak eskuartze globala eta holistikoa egingo du, non bizitzaren parte-hartzeko maila guztiak kontuan hartuko diren, eskuartze hobeagoa eta eraginkorragoa lortzeko.
Gizarte-hezkuntzak erresilientziaren garapena lortuko du pertsonari (erabiltzaileari) laguntza ematen, akonpainamendu-prozesu baten barruan, egunerokotasunean. Gure presentzia eskaini behar dugu distantziakidetasunez, akonpainamendua eginez, erabakietan parte-hartuta, akatsetan eta arrakastetan egonda eta gertatzen den eboluzioaren analisia eginda, betiere, errespetuz (Pérez Hoyos et al., 2014). Amaitzeko, garrantzitsuena erabiltzaileen bizi kalitatea hobetzea dela esan behar dugu, eta, horretarako ahalik eta profesional hoberenak izaten saiatu behar gara. 
ALDWIN, C. (2007): Stress, Coping and Development, Londres, The Guilford Press.

ARRINGTON, E. eta WILSON, M.A (2000): “Re-examination of risk and resilience during adolescence: Incorporating culture and diversity", Journal of Child and Family Studies, 2. zb., 221-230 or.

CRESPO, P.; DE RHAM, P.; GONZÁLEZ, G.; ITURRALDE, P.; JARAMILLO, B.; MANCERO, L.; MONCADA, M.; PÉREZ, A. eta SORIA, C. (2005): Empoderamiento: conceptos y orientaciones, serie Reflexiones y Aprendizajes, Quito, Servicio de Gestión del Conocimiento para Latinoamérica y El Caribe, 〈http://www. asocam.org/node/52171>.

BANDURA, A. (2001): "Social cognitive theory: An agentic perspective", Annual Review of Psychology, 52. zb., $1-26$ or.

BANKS, J. (2004): “Teaching for social justice, diversity and citizenship in a Global world", The Educational Forum, 68. zb., 289-298 or.

BECOÑA, E. (2006): “Resiliencia: definición, características y utilidad del concepto", Revista de Psicopatología y Psicología Clínica, 11. zb., 125-146 or.

BRONFENBRENNER, U. (1987): La ecología del desarrollo humano, Bartzelona, Paidós,

CABANYES, J. (2010): "Resiliencia: una aproximación al concepto”, Revista Psiquiatria Salud Mental, 4. zb., $145-151$ or.

CICCHETTI, D. (2003): “Foreword”, in LUTHAR, S. (arg.), Resilience and Vulnerability. Adaptation in the Context of Chilhood Adversities, Cambridge, Cambridge University Press, 19-27 or.

CYRULNIK, B. (2002): Los patitos feos, Bartzelona, Gedisa.
- (2008): El amor que nos cura, Bartzelona, RBA.

- (2010): Me acuerdo, Bartzelona, Gedisa.

DE LA PAZ, P.; RODRÍGUEZ, V. eta MERCADO, E. (2014): "Nuevas tendencias de intervención en Trabajo Social”, Revista Internacional de Trabajo Social y Bienestar, 3. zb., 223-228 or.

ESCUDERO ESPINALT, E. (2014): “Las historias de vida como herramienta para el empoderamiento", in SILVESTRE, M.; ROYO, R. eta ESCUDERO ESPINALT, E. (arg.), El empoderamiento de las mujeres como estrategia de intervención social, Bilbo, Deustuko Unibertsitatea, $27-38$ or.

FRANKL, V.E. (1981): El hombre en busca de sentido, Bartzelona, Herder.

FREDERICKS, B. (2008): "Which way that empowerment? Aboriginal women's narratives of empowerment", Alternative, 2. zb., 7-19 or.

FREIRE, P. (1975): Pedagogía del oprimido, Madril, Siglo XXI.

GARMEZY, N. (1974): “Children at risk: The search for the antecedents of schizophrenia", Schizophrenia Bulletin, 8. zb., 14-90 or.

ILLICH, I. (1971): La sociedad desescolarizada, Mexiko 〈http://peuma.e.p.f.unblog.fr/files/2012/06/ ILLICH-la-sociedad-desescolarizada1.pdf〉.

JACKSON, Y. eta WARREN, J. (2000): “Appraisal, social support, and life events: Predicting outcome behavior in school-age children", Child Development, 71. zb., 1.441-1.457 or.

JUÁREZ, A. eta LÁZARO, S. (2014): "El enfoque de fortalezas en Trabajo Social”, Miscelánea Comillas, 72. zb., 143-158 or.

KABEER, N. (1999): “Empoderamiento desde abajo: ¿qué podemos aprender de las organizaciones de 
base?", in LEÓN, M., Poder y empoderamiento de las mujeres, Santa Fe, TM Editores, 119-146 or.

LEONARDSEN, D. (2007): "Empowerment in social work: An individual vs. a relational perspective", International Journal of Social Welfare, 16. zb., 3-11 or.

LLOBET ESTANY, M. (2014): “Algunas reflexiones acerca del proceso de empoderamiento de mujeres al frente de familias monomarentales en Barcelona y Pamplona", in SILVESTRE, M.; ROYO R. eta ESCUDERO ESPINALT, E. (arg.): El empoderamiento de las mujeres como estrategia de intervención social, Bilbo, Deustuko Unibertsitatea, 457-470 or.

LORD, J. eta HUTCHISON, P. (1993): “The process of empowerment: Implications for theory and practice", Canadian Journal of Community Mental Health, 1. zb., 5-22 or.

LUTHAR, S. (2006): "Resilience in development: A synthesis of research across five decades", in CICCHETTI, D. eta COHEN, D. (arg.), Developmental Psychopathology: Risk, Disorder, and Adaptation, 2. argit., New York, Wiley, 739-795 or.

MAGGS, J.; FROME, P.; ECCLES, J. eta BARBER, B. (1997): "Psychosocial resources, adolescent risk behaviour, and young adult adjustment: Is risk taking more dangerous for some than others?", Journal of Adolescence, 20. zb., 103-119 or.

MAIZTEGUI, C. (2011): Empoderamiento, participación y ciudadanía [argitaratu gabekoa].

MARTÍNEZ-PAMPLIEGA, A.; SANTIBÁÑEZ, R.; PRIETO PRIETO, T. eta RUIZ-NAREZO, M. (2013): “Riesgo psicosocial y promoción de la resiliencia”, in SANTIBÁÑEZ, R. eta MARTÍNEZ-PAMPLIEGA, A. (arg.), Intervención comunitaria con adolescentes y familias en riesgo, Bartzelona, Graó, 45-58 or.

MASTEN, A.; HUBBARD, J.; GEST, S.; TELLEGEN, A.; GARMEZY, N. eta RAMÍREZ, M. (1999): "Competence in the context of adversity: Pathways to resilience and maladaptation from childhood to adolescence", Development and Psychopathology, 11. zb., 143-169 or.

MONTAGUT, M. (2008): “Educación social, ciudadanía y tercer sector”, Educación Social, Revista de Intervención Socioeducativa, 38. zb., 107-120 or.

MUÑOZ-RIVAS, M. eta GRAÑA, J. (2001): "Efectos de riesgo y de protección para el consumo de drogas en adolescentes", Psicothema, 13. zb., 87-94 or.

NAZIO BATUAK (1995): Informe de la Cuarta Conferencia Mundial sobre la Mujer, Beijing, 4 a 15 de septiembre de 1995, New York, Nazio Batuak, <http://www.un.org/womenwatch/daw/ beijing/pdf/Beijing\%2ofull\%2oreport\%20S. pdf〉.

NARAYAN, D. (2005): “Conceptual framework and methodological challenges", in NARAYA, D. (arg.): Measuring Empowerment. Crossdisciplinary Perspectives, Washington DC, World Bank, 3-38 or.

OLIVA, A.; JIMÉNEZ MORAGO, J.M.; PARRA JIMÉNEZ, A. eta SÁNCHEZ-QUEIJA, I. (2008): “Acontecimientos vitales estresantes, resiliencia y ajuste adolescente", Revista de Psicopatología y

Psicología Clínica, 1. zb., 53-62 or.

PARRA RAMAJO, B. (2014): “Perspectivas de empoderamiento: el poder de transformación y cambio social de los grupo", in SILVESTRE, M.; ROYO, R. eta ESCUDERO ESPINALT, E. (arg.), El empoderamiento de las mujeres como estrategia de intervención social, Bilbo, Deustuko Unibertsitatea, 205-210 or.

PEREIRA, R. (2011): Adolescentes en el siglo XXI. Entre impotencia, resiliencia y poder, Madril, Morata.

PÉREZ BLASCO, J.; FERRI, F.; MELIÁ, A. eta MIRANDA, A. (2007): "Resiliencia y riesgo en niños con dificultades de aprendizaje", Revista de Neurología, 2. zb., 9-12 or.

PÉREZ HOYOS, J.; RUIZ-NAREZO, M.; MARTÍNEZ RUEDA, N. eta SANTIBÁÑEZ, R. (2014): “Adolescencia en riesgo. Acompañamiento y trabajo en red como herramientas de intervención", in DEL POZO SERRANO, F.J. eta PELÁEZ PAZ, C. (koord.), Educación Social en situaciones de riesgo y conflicto en Iberoamérica Madril, Universidad Complutense de Madrid, 423-430 or.

PICAZA, M. (2015): “Entre el 'poder sobre’ y el 'poder compartido': construyendo relaciones de pareja más igualitarias desde la adolescencia", in JIMÉNEZ HERNÁNDEZ, A.S.; PANTOJA, A.; LEIVA, J.J.; MORENO SÁNCHEZ, E. eta GUTIÉRREZSÁNCHEZ J.D. (koord.) Congreso Internacional Infancia en Contextos de Riesgo, Asociación Infancia, Cultura y Educación, 〈https://www. bizkailab.deusto.es/wp-content/uploads/2015/ 03/2PikazaRuizFonsekaGzSanti-ComunicacionPoderSobrePoderCompartido-2014.pdf .

QUAMMA, J. eta GREENBERG, M. (1994): “Children's experience of life stressors: The role of family social support and social problem-solving skills as protective factors", Journal of Child Clinical Psychology, 23. zb., 295-305 or.

QUINTERO, A. (2005): "Resiliencia: contexto no clínico para trabajo social", Revista Latinoamericana de Ciencias Sociales Niñez y Juventud, 3. zb., 73-94 or.

RODRIGO, M.; MAÍZQUEZ, M. eta MARTÍN, J. (2010): Parentalidad positiva y políticas locales de apoyo a las familias, Madril, Ministerio de Sanidad y Política Social; Federación Española de Municipios y Provincias.

RODRÍGUEZ-CASADEVALL, A.; MORATA, T. eta MURO, P. (2014): Empoderamiento y desarrollo comunitario en India: mujeres en el ámbito de la prostitución. in SILVESTRE, M.; ROYO, R. eta ESCUDERO ESPINALT, E. (arg.), El empoderamiento de las mujeres como estrategia de intervención social, Bilbo, Deustuko Unibertsitatea, 211-222 or.

RODRÍGUEZ FERNÁNDEZ, C.; SALVADOR PEDRAZA, M.J eta HERNÁNDEZ ECHEGARAY, A. (2014): "Intervención social centrada en el empoderamiento de las mujeres en el medio rural: una experiencia de la provincia de Valladolid a analizar", in SILVESTRE, M.; ROYO, R. eta ESCUDERO ESPINALT, E. (arg.), El empoderamiento de las mujeres como estrategia de intervención social, Bilbo, Deustuko Unibertsitatea, 223-236 or. 
RUBIO SERRANO, J. (2014): "Estrategias de empoderamiento para la inclusión con equidad", in SILVESTRE, M.; ROYO, R. eta ESCUDERO ESPINALT, E. (arg.), El empoderamiento de las mujeres como estrategia de intervención social, Bilbo, Deustuko Unibertsitatea, 251-255 or.

RUTTER, M. (1987): "Psychological resilience and protective mechanisms", American Journal of Orthopsychiatry, 57. zb., 316-331 or.

- (2007): "Resilience, competence and coping", Child Abuse Neglect, 31. bol., 3. zb., 205-209 or.

SANTIBÁÑEZ, R.; FONSECA, I.; GONZÁLEZ DE AUDIKANA, M. eta FERNÁNDEZ DE LIGER, Z. (2013): "Recomendaciones para una buena práctica en la intervención con adolescencia en riesgo y familias", in SANTIBÁÑEZ, R. eta MARTíNEZPAMPLIEGA, A. (arg.), Intervención comunitaria con adolescentes y familias en riesgo, Bartzelona, Graó, 151-164 or.

SEN, A. (1985): "Well-being, agency and freedom: The Dewey Lectures 1984", The Journal of Philosophy, 4. zb., $165-221$ or.

SHAW, A. et al. (2012): Youth Civic Engagement in Nonformal Education, Galway, Unesco Child and Family Research Centre.

SMITH, J. eta PRIOR, M. (1995): “Temperament and stress resilience in school-age children: A within families study", Journal of the American Academy of Child \& Adolescent Psychiatry, 34 bol., 2. zb.,168-179 or.

TENGLAND, P.A. (2008): “Empowerment: A conceptual discussion", Health Care Analysis, 16. bol., 2. zb., 77-96 or.
TREVITHICK, P. (2006): Habilidades de comunicación e intervención social. Manual práctico, Madril, Narcea.

TORRES DEL CASTIILLO, R.M. (2009): De la alfabetización al aprendizaje a lo largo de toda la vida: tendencias, temas y desafíos de la educación de personas jóvenes y adultas en América Latina y el Caribe, [Hamburg], Instituto de la Unesco para el Aprendizaje a lo Largo de Toda la Vida, 〈https://www.oei.es/historico/alfabetizacion/ epja_lac_informe_final_abril_2009.pdf .

UNGAR, M. (2010): “Families as navigators and negotiators: Facilitating culturally and contextually specific expressions of resilience", Family Process, 3. zb., 421-435 or.

VINACCIA, S.; QUICENO, J. eta MORENO SAN PEDRO, E. (2007): "Resiliencia en adolescentes", Revista Colombiana de Psicología, 16. zb., 139-146 or.

WERNER, E. (1989): "High-risk children in young adulthood. A longitudinal study from birth to 32 years", American Journal of Orthopsychiatry, 59. zb., 72-81 or.

WERNER, E. eta SMITH, E. (1982): Vulnerable but Invencible: A Study of Resilient Children, New York, McGraw Hill.

ZIMMERMARN, M.A. (2000): “Empowerment theory: Psychological, Organizational and Community Levels of Analysis", in RAPPAPORT, J eta SEIDMAN, E. (arg.), Handbook of Community Psychology, New York, Kluwer Academic, 43-63 or. 